British Journal of Pharmaceutical Research

1(1): 1-8, 2011

SCIENCEDOMAIN international

www.sciencedomain.org

\title{
Evaluation of the Phytochemical Composition and Hypoglycaemic Activity of Methanolic Leaves Extract of Costus afer in Albino Rats
}

\author{
S. Momoh $^{2}$, O. W. Yusuf ${ }^{2}$, M. M. Adamu ${ }^{2}$, \\ C.O. C. Agwu and F. O. Atanu ${ }^{182^{*}}$ \\ ${ }^{1}$ School of Biological Sciences, University of Reading, United Kingdom (UK) \\ ${ }^{2}$ Department of Biochemistry; ${ }^{3}$ Department of Biological Sciences, \\ Faculty of Natural Sciences, Kogi State University, Anyigba, Nigeria.
}

Research Article

Received $17^{\text {th }}$ February 2011

Accepted $5^{\text {th }}$ March 2011

Online Ready $10^{\text {th }}$ March 2011

\section{ABSTRACT}

Medicinal plants are reservoirs of natural products with anti-diabetic potentials. In the present study we screened Costus afer for the presence of plant products and to study the effects of the methanolic leaf extract of the plant on fasting blood glucose of normal rats. Adult male wistar strain albino rats were given graded doses $(200-800 \mathrm{mg} / \mathrm{kg})$ of the methanolic leaf extract of Costus afer, standard hypoglycaemic drug glibenclamide or a combination of the two in the presence or absence of oral glucose feeding. Fasting blood glucose was monitored for 6 hours post administration of drugs. Phytochemical studies revealed relative amounts of alkaloids, flavanoids, tannins, phenols, glycosides and terpenoids. Costus afer showed significant hypoglycaemic effect $(p<0.05)$ comparable with the standard drug. However, the plant extract did not reduce blood glucose in glucose fed rats. Also, a combination of plant extract and glibenclamide caused a significant reduction in fasting blood sugar of both glucose loaded and unloaded rats. The results validate the use of Costus afer as a hypoglycaemic plant in native medicine. These effects could be attributed to its phytochemical constituents. Costus afer could be a promising plant for the development of anti-diabetic drugs. 
Keywords: Hypoglycaemia, phytochemicals, diabetes mellitus, Costus afer;

\section{INTRODUCTION}

Diabetes mellitus is an endocrine and metabolic disorder that poses considerable threat worldwide in the $21^{\text {st }}$ century (Adewole and Ojewole, 2009). The central identifying features of diabetes mellitus are hyperglycemia, hypoinsulinemia, dyslipidemia. Currently diabetes is controlled by diet, exercise, insulin replacement therapy and by the use of herbal hypoglycemic agents (Mallick et al., 2007).

However, available oral hypoglycemic drugs have many side effects such as nausea and vomiting, cholestatic jaundice, agranulocytosis, aplastic and hemolytic anemias, generalized hypersensitivity reactions, dermatological reaction and lactic acidosis.

Therefore, searching for effective, low cost and less side effected hypoglycemic agents is important. In the past experimental evidences have in the past confirmed the hypoglycaemic activity of a number of indigenous African medicinal plants. Furthermore, after the recommendations made by the WHO on diabetes mellitus, investigations on hypoglycaemic agents from medicinal plants have become more important and the search for more effective and safer hypoglycaemic agents has continued to be an important area of active research. World ethnobotanical information about medicinal plants reports that almost 800 plants could be used to control diabetes mellitus (DM) (Udayakumar et al., 2009).

Costus afer also known as ginger lily or bush cane (Iwu, 1993) is common in many parts of the world and also to the people of Nigeria. In Nigeria, among the Ibos, it is commonly called "okpete", "okpoto" or "okpete ohia" (Iwu, 1983), Hausas, it is called "kakizuwa", Yorubas call it "tete-egun" and the Efik, "mbritem" (Iwu, 1993). The succulent stem is chewed as a remedy for cough. The root decoction is administered for the treatment of sleeping sickness and stomach ache (Iwu, 1993). Most important to this work is the use of this plant in the treatment of diabetes mellitus in folklore medicine (Udem and Ezeasorm, 2010).

This study is designed to screen the phytochemical constituents of the leaves of this plant and also to study its effect on blood glucose of rats.

\section{METHODOLOGY}

\subsection{PLANT MATERIAL}

Fresh leaves of Costus afer were collected in the month of February from Oganaji area of Anyigba, Nigeria. They were thereafter authenticated in the Department of Biological Sciences, Kogi State University, Anyigba, Nigeria. The plant leaves were washed, air dried and pulverized. To obtain the methanolic extracts, $800 \mathrm{~g}$ of plant material was soaked in 2 litres of methanol for 48 hours. The residue was removed by filteration and the filterate was concentrated under reduced pressure by a rotary evaporator at $40{ }^{\circ} \mathrm{C}$. 


\subsection{PHYTOCHEMICAL SCREENING OF PLANT EXTRACT}

A small portion of the dry extract was used for the phytochemical tests for compounds which include alkaloids, flavonoids, tannins, saponins, glycosides, phenol and terpenoids in accordance with the methods of Harbone (1998), Trease and Evans (1996) and Sofowara (2006). Phytochemical screening was done by physical examination of intensity of the colour of reaction mixture compared with blanks (i.e., without of plant samples) and highest possible intensity of colour type.

\subsection{ANIMALS}

Adult male wistar albino rats weighing 180-200 g were acclimatized for a period of 15 days at room temperature of $25^{\circ} \mathrm{C}$, relative humidity of $70-80 \%$ and 12 hour dark/light cycle. They were housed in the animal house of Department of Biochemistry, Kogi State University, Nigeria and fed with standard pellets and water ad libitum.

\subsection{EXPERIMENTAL DESIGN}

Experimental rats fasted for 12 hours were divided into 10 groups of 6 rats each. Animals received either standard hypoglycaemic drug glibenclamide (GB), graded doses of leaf extract (LE) of Costus afer, LE + glucose, LE + GB or Costus afer + GB + glucose as follows:

Group 1- Normal control (distilled water)

Group 2- Glibenclamide (GB) $5 \mathrm{mg} / \mathrm{kg}$ body weight

Group 3- LE $200 \mathrm{mg} / \mathrm{kg}$ body weight

Group 4- LE $400 \mathrm{mg} / \mathrm{kg}$ body weight

Group 5- LE $800 \mathrm{mg} / \mathrm{kg}$ body weight

Group 6- LE $200 \mathrm{mg} / \mathrm{kg}$ + Glucose $2 \mathrm{~g} / \mathrm{kg}$ body weight

Group 7- LE $400 \mathrm{mg} / \mathrm{kg}$ + Glucose $2 \mathrm{~g} / \mathrm{kg}$ body weight

Group 8- LE $800 \mathrm{mg} / \mathrm{kg}+$ Glucose $2 \mathrm{~g} / \mathrm{kg}$ body weight

Group 9- LE $400 \mathrm{mg} / \mathrm{kg}+2.5 \mathrm{mg} / \mathrm{kg}$ GB body weight

Group 10- LE $400 \mathrm{mg} / \mathrm{kg}+2.5 \mathrm{mg} / \mathrm{kg} \mathrm{GB}+$ Glucose $2 \mathrm{~g} / \mathrm{kg}$ body weight

All treatments were administered at single dose by gavage and glucose level was monitored over 6 hours. In the case of glucose administration animals were pre-treated with the plant extract 1 hour before oral glucose administration.

\subsection{HYPOGLYCAEMIC STUDY IN NORMAL RATS}

The blood of animals was collected by tail bleeding and their fasting blood glucose estimated by an automatic one touch glucometer. Initial blood glucose level was compared with change in glucose level over 6 hours post administration of drugs.

\subsection{HYPOGLYCAEMIC STUDY IN GLUCOSE FED RATS}

Glucose was dissolved in distilled water and administered at a dose of $2 \mathrm{~g} / \mathrm{kg}$ body weight of rats one hour after an administration of a single dose of drug. The blood glucose level was thereafter monitored for 5 hours. Co-administration studies of GB and LE was designed to determine the complementarities of the two regimens. 


\subsection{STATISTICAL ANALYSIS}

Standard statistical package SPSS 15.0 was used to compute analysis of variance (ANOVA) at a significance level of $p<0.05$. Each result is a mean of at least 5 determinations.

\section{RESULTS AND DISCUSSION}

Results of phytochemical screening revealed that the plant extract contains appreciable amount of terpenoids; moderate amounts of alkaloids, flavanoids, phenols; and trace amount of tannins, saponins and glycosides (Table 1).

Oral administration of the methanolic leaf extract of Costus afer showed a dose dependent hypoglycemic effect as revealed in Figure 1. Doses of $200 \mathrm{mg} / \mathrm{kg}$ and $800 \mathrm{mg} / \mathrm{kg}$ produced significant hyoglycemic effect in fasted normal rats by $34.22 \%$ and $59.21 \%$, respectively. Oral administration of $5 \mathrm{mg} / \mathrm{kg}$ glibenclamide also caused significant reduction $(p<0.05)$ in fasting blood glucose comparable with $200 \mathrm{mg} / \mathrm{kg}$ LE but much less than $800 \mathrm{mg} / \mathrm{kg} \mathrm{LE}$. Contrary to this is a rapid increase $(p<0.05)$ in fasting blood glucose experienced when glucose was co-administered with the LE as shown in Figure 2.

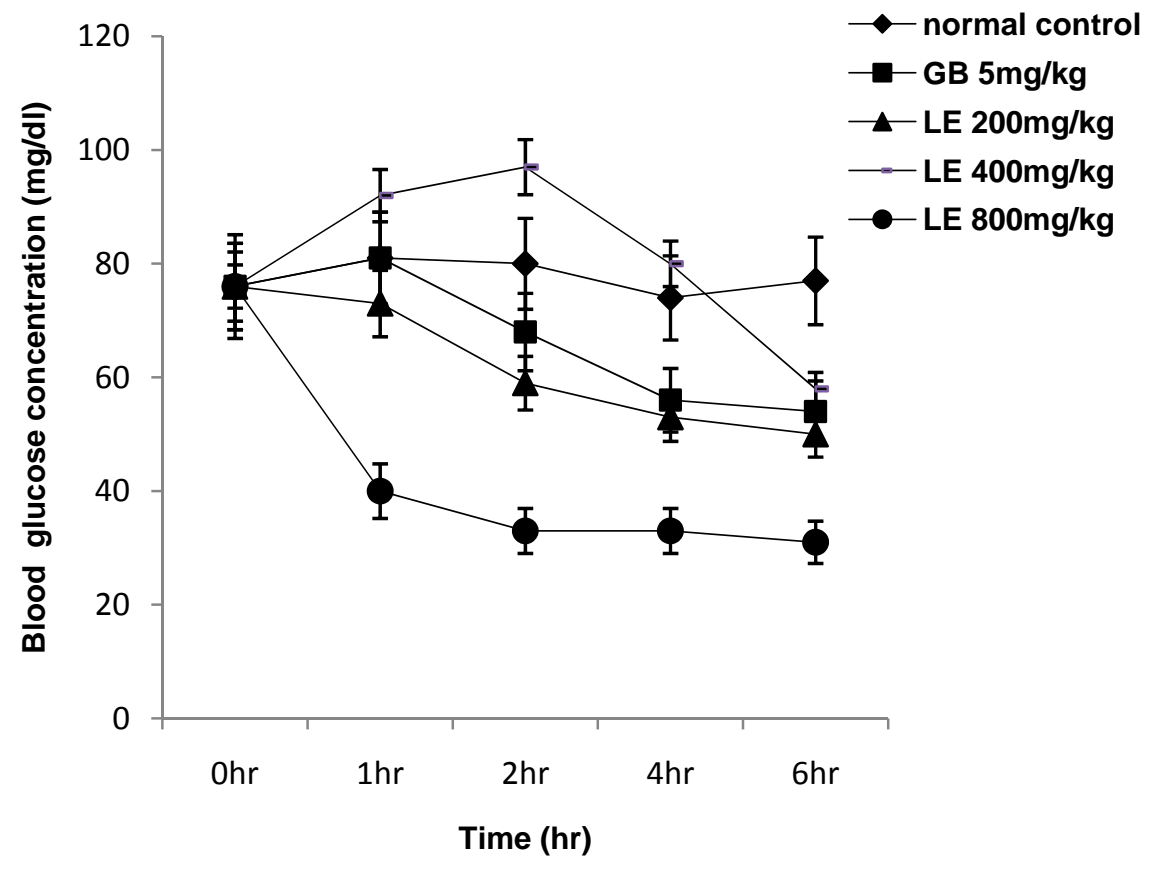

Fig. 1. Effect of varied doses of methanolic leaf extract of Costus afer on the fasting blood sugar of normoglycaemic rats (LE- Leaf extract ; GB-Glibenclamide) 
Studies for complementarities of LE and GB displayed positive results. As shown in figure 3, co-administration of $400 \mathrm{mg} / \mathrm{kg}$ LE and $2.5 \mathrm{mg} / \mathrm{kg}$ GB caused a $56.58 \%$ and $36.84 \%$ reduction in fasting blood sugar over 6 hours in the absence and presence of oral glucose feeding respectively.

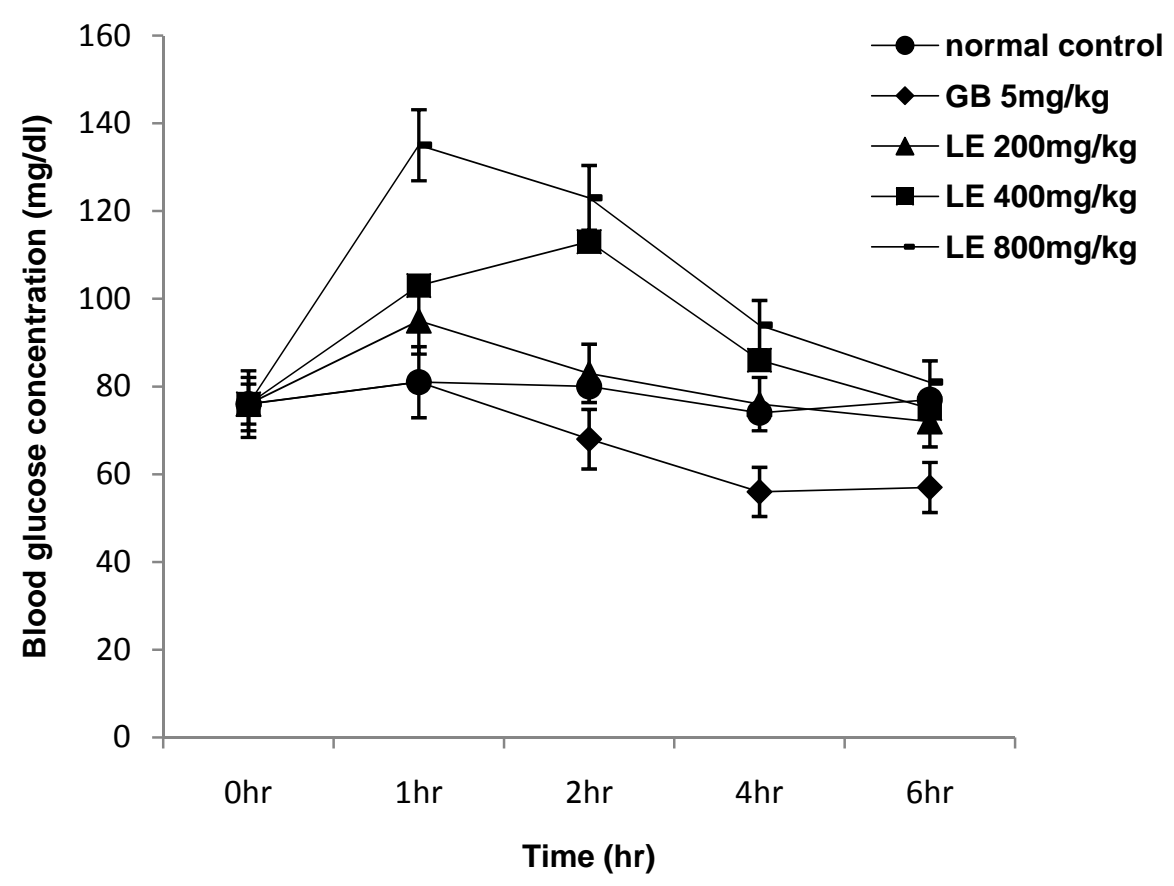

Fig. 2. Effect of varied doses of methanolic leaf extract of Costus afer on oral glucose tolerance of normal rats (LE- Leaf extract ; GB-Glibenclamide)

Table 1. Qualitative analysis of phytochemcal constituents of leaf extract of Costus afer

\begin{tabular}{rl|l}
\hline Compounds & Presence \\
\cline { 2 - 3 } & Alkaloids & ++ \\
& Flavanoids & ++ \\
& Tannins & + \\
& Saponin & + \\
& Glycosides & + \\
& Phenol & ++ \\
& Terpenoids & +++ \\
\hline amount; ++ moderate amount; + trace amount
\end{tabular}


The use of medicinal plants in the treatment of diabetes mellitus is an age long practice. We investigated the phytochemical composition of leaves of Costus afer and also studied the effects of its methanolic extract on fasting blood glucose of rats.

From phytochemical analysis, it was found that the major constituents of the extract were terpenoids, flavonoids, phenols, alkaloids, glycosides and tannins. Over 150 plants extracts and some of their active principles including flavonoids are known to be used for the treatment of diabetes (Meiselman et al., 1976; Choi et al., 1991; Hassig et al., 1999; Chude et al., 2001). Moreover, tannin-containing drug demonstrated antidiabetic activity (Iwu, 1983, 1980; Klein et al, 2007). Similarly, several phenolic compounds and flavonoid possess marked anti-diabetic activity (Hsu et al., 2000). Possibly the insulin-like activity of these bioactive compounds inherent in Costus afer is responsible for its hypoglycaemic effects.

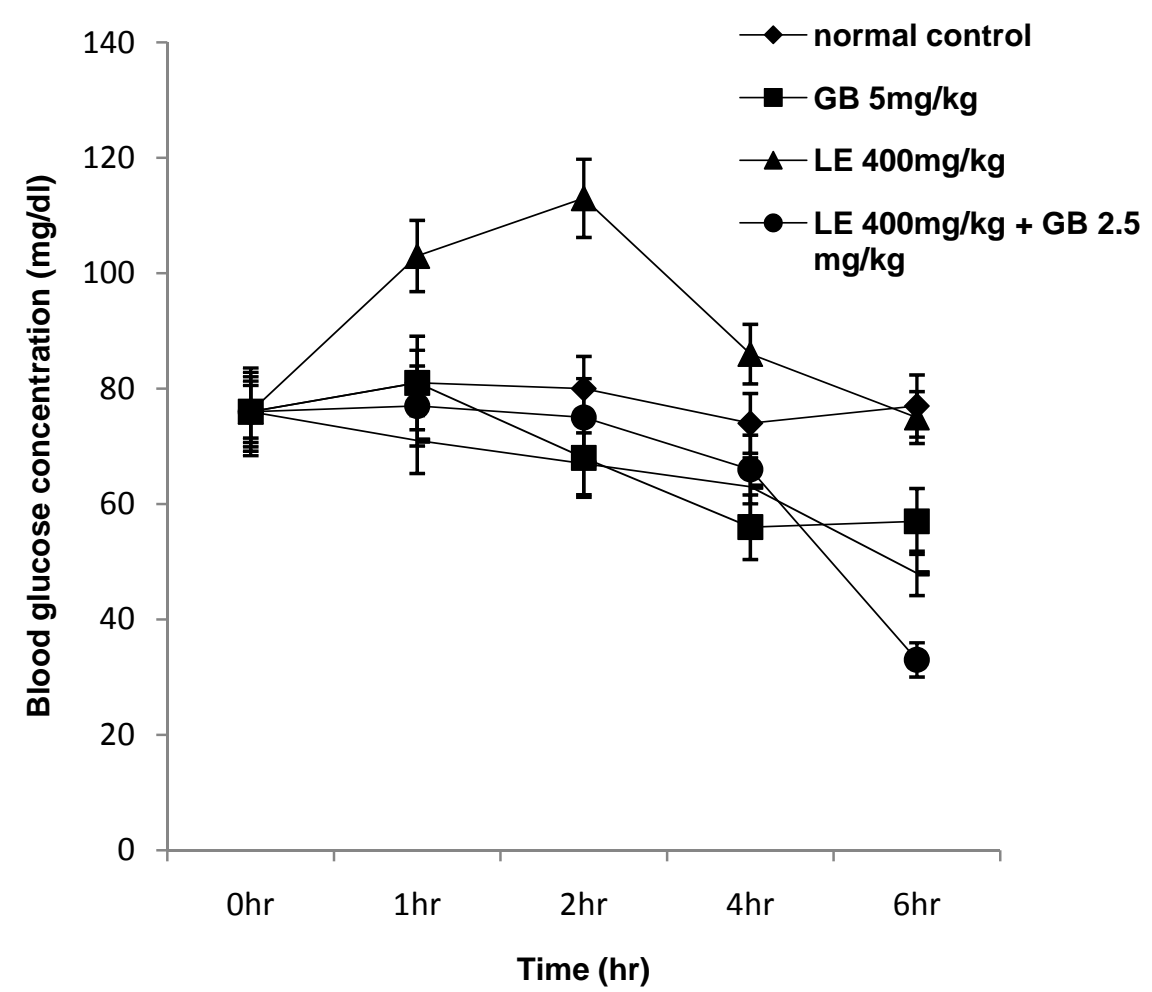

Fig. 3. Effect of co-adminstration of methanolic leaf extract of Costus afer and glibenclamide on glucose tolerance of normal rats (LE- Leaf extract ; GB-Glibenclamide)

The bioactive agents possibly mobilised glucose to their store while decreasing the blood glucose level. On the contrary methanolic leaf extract of Costus afer caused a rapid increase of blood glucose level. While the explanation may be farfetched, it could be opined that may 
be glucose and the bioactives in the plant material are competing for same binding sites thereby inhibiting glucose uptake from the blood. Positive results from the experiments utilising both glibenclamide and the plant extract points at the possibility of using both in complementary treatment of diabetes mellitus without fear of drug-drug interaction.

\section{CONCLUSION}

This study reveals that Costus afer contains anti-diabetic drug principles that require further characterization.

\section{ACKNOWLEDGMENTS}

We are very thankful to Mr. Friday Emmanuel and other members of staff of the Laboratory of Biochemistry, Kogi State University for their technical assistance.

\section{REFERENCES}

Adewole, S.O., Ojewole, J.A.O. (2009). Protective effects Of Annona muricata linn. (Annonaceae) leaf aqueous extract on serum lipid profiles and oxidative stress in hepatocytes of Streptozotocin-treated diabetic rats. Afr. J. Trad. Cam., 6(1), $30-41$.

Choi, J.S., Yokozawa, T., Oura, H. (1991). Improvement of hyperglycaemia and hyperlipemia in streptozotocin-diabetic rats by a methanolic extract of prunus davidiana stems and its main component, Prunin. Planta Medica, 57(3), 208-211.

Harbone, J.B. (1998). Methods of Extraction and Isolation. In: Phytochemical Methods, Chapman and Hall, London, Pp. 60-66.

Hassig. A., Liang, W.X., Schwabl, H., Stampfli, K. (1999). Flavonoids and tannins: plantbased antioxidants with vitamin character. Med Hypotheses, 52, 479-81.

Hsu, F.L., Chen, Y.C., Cheng, J.T. (2000). Caffeic Acid As Active Principle From The Fruit Of Xanthium Strumarium To Lower Plasma Glucose In Diabetic Rats. Plant Med., 66, 228-230.

Iwu, M.M. (1983). Traditional Igbo medicine. Institute of African studies, University of Nigeria, Nsukka, Pp 122-144.

Iwu, M.M. (1993). Handbook of African Medicinal Plants. Crc Press, London, Pp 161-162.

Iwu, M.M. (1980). Antidiabetic properties of Bridelia ferruginea leaves. Planta Medica, 39, 247.

Iwu, M M (1983). The Hypoglycaemic properties of Bridelia ferrugineaFitoterapia, 54(6), 243-248.

Klein, G., Kim, J., Himmeldirk, K., Cao, Y., Chen, X. (2007). Antidiabetes an d anti-obesity activity of lagerstroemia speciosa. Evidence-Based Complementary and Alternative Medicine (Ecam), 4(4), 401-407.

Mallick, C., Chatterjee, K., Guhabiswas, M., Ghosh, D. (2007). Antihyperglycemic effects of separate and composite extract of root of musa paradisiaca and leaf of coccinia indica in streptozotocin-induced diabetic male albino rat. Afr. J. Trad. Cam., 4(3), $362-371$.

Meiselman, H.L., Halpern, B.P., Dateo, G.P. (1976). Reduction of sweetness judgments by extracts from the leaves of Ziziphus jujuba. Physiol. Behavior, 17(2), 313-317.

Sofowara, A. (2006). Medical Plants and Traditional Medicine in Africa. Rep. Edition, Spectrum Books Ltd., Ibadan, Pp. 150. 
Trease, G.E., Evans, W.C. (1996). Pharmacognosy, $4^{\text {th }}$ Edition, W.B. Sounders, USA, Pp. 243-283.

Udayakumar, R., Kasthurirengan, S., Mariashibu, T.S., Rajesh, M., Anbazhagan, V.R., Kim, S.C., Ganapathi, A., Choi, W.C. (2009). Hypoglycaemic and hypolipidaemic effects of withania Somnifera root and leaf extracts on alloxan-induced Diabetic rats. Int. J. Mol. Sci., 10, 2367-2382.

Udem, S.C., Ezeasor, C.K. (2010). The acute and subchronic toxicity studies of aqueous leaf and stem bark extract of Costus afer ker (zingiberaceae) in mice. Comp. Clin. Pathol., 19, 75-80.

(C) 2011 Momoh et al.; This is an Open Access article distributed under the terms of the Creative Commons Attribution License (http://creativecommons.org/licenses/by/2.0), which permits unrestricted use, distribution, and reproduction in any medium, provided the original work is properly cited. 